\title{
KRISIS IDENTITAS BUDAYA: STUDI POSKOLONIAL PADA PRODUK DESAIN KONTEMPORER
}

\author{
Wirawan Sukarwo \\ Program Studi Desain Komunikasi Visual \\ Fakultas Bahasa Dan Seni, Universitas Indraprasta PGRI \\ wirawansukarwo@gmail.com
}

\begin{abstract}
Abstrak
Pembentukan identitas nasional di tengah tingginya diversitas budaya merupakan polemik bangsa bekas terjajah, seperti Indonesia. Krisis identitas yang melanda tersebut disebabkan oleh tiga faktor, yaitu konsep identitas, politik kebudayaan, dan kapitalisme global. Sebagai bangsa bekas terjajah, Indonesia masuk ke fase penjajahan baru yang tidak lagi bersifat fisik melainkan mental. Teori poskolonial membantu para praktisis desain untuk mengurai dan membangun kesadaran kolektif akan situasi krisis ini. Melalui konsep hibridisasi budaya dan mimikri, produk-produk desain kontemporer memberikan ruang untuk mengaktualisasikan narasi kebudayaan daerah yang terpinggirkan. Pada titik inilah, produk desain komunikasi visual dapat menjadi juru bicara kelompok subaltern dalam konteks kebudayaan daerah.
\end{abstract}

Kata kunci: Krisis identitas budaya, poskolonial, hibriditas, mimikri.

\begin{abstract}
The construction of national identity in the middle of high cultural diversity is a polemic to former colonized peoples such as Indonesia. The identity crisis that hit was caused by three factors namely; the concept of identity, cultural policies, and global capitalism. As a former colonized nation, Indonesia entered into a new colonial phase that is no longer physically but mentally. Postcolonial theory helps design practitioners to parse and build a collective awareness of this crisis situation. Through the concept of cultural hybridization and mimicry, contemporary design products provide space to actualize the narratives of marginalized local cultures. At this point, visual communication design products can be the spokesperson of the subaltern group in the context of regional culture.
\end{abstract}

Key words: Cultural identity crisis, postcolonial, hybridity, mimicry. 


\section{PENDAHULUAN}

Indonesia adalah negara yang tercatat memiliki diversitas budaya tertinggi di dunia. Predikat ini memberikan problematika tersendiri ketika usaha serius pencarian identitas budaya nasional baru dimulai pada masa-masa kemerdekaan. Integrasi dan penyatuan di tengah keragaman menjadi pekerjaan yang tidak pernah selesai sampai hari ini. Selama berabad-abad sebelumnya, diversitas tersebut telah menjadi sarana yang efisien bagi pihak penjajah untuk memperkuat penguasaan atas negeri jajahan. Rezim kolonial mengelola segala perbedaan budaya di antara suku bangsa di Nusantara untuk menentukan atribut dan perilaku rakyat jajahan seperti yang mereka inginkan.

Mulai dari era revolusi kemerdekaan Indonesia sampai dengan masa reformasi, diversitas budaya tetap menjadi pekerjaan rumah yang belum selesai. Semangat untuk menyatukan seluruh elemen masyarakat adat dalam bungkus nasionalisme tidak pernah berhasil memuaskan seluruh pihak. Mulai dari rezim Presiden Soekarno hingga hari ini, identitas nasional dalam ranah kebudayaan masih dalam proses pembentukan.

Keilmuan desain komunikasi visual mengisi peran strategis sekaligus gamang dalam proses pembentukan identitas budaya ini. Di satu sisi, keilmuan desain memiliki preferensi yang sangat kuat untuk melestarikan dan mengaktualisasikan nilai-nilai budaya tradisional. Hal tersebut ditunjukkan dengan maraknya produk-produk budaya kontemporer yang memiliki tendensi pelestarian kebudayaan lokal. Riset dan perancangan yang dilakukan para akademisi pada keilmuan ini juga menunjukkan semangat yang jelas pada isuisu konservasi budaya. Namun, di sisi lain, keilmuan desain sangat berkaitan dengan perkembangan industri budaya pada masyarakat kapitalisme muktahir yang sejatinya memiliki banyak paradoks.

Makalah ini memberi sebuah pengantar studi poskolonial yang dipakai secara praktis sebagai teori kritik pada perkembangan produk budaya kontemporer, khususnya produk-produk desain komunikasi visual. Konsep seperti hibridisasi budaya dan mimikri yang merupakan turunan langsung dari teori poskolonial merupakan salah satu jalan tengah untuk menghubungkan kebutuhan akan konservasi budaya di satu sisi dengan modernisasi di sisi lain.

Seorang desainer komunikasi visual, tidak ubahnya seperti seniman, sastrawan, dan para agen kebudayaan lainnya yang terus-menerus membentuk gagasan mengenai identitas. Melalui produk-produk desain kontemporer seperti animasi, poster, komik, infografis dan lain-lain, identitas nasional bisa dibangun dengan kerangka yang independen dan memiliki subjektivitas tinggi. Independensi tersebut pada gilirannya akan menjadi modal kuat bagi negara untuk menghadapi berbagai tantangan di era globalisasi.

\section{PEMBAHASAN}

\section{Krisis Identitas Budaya}

Setidaknya, ada tiga hal yang menjadi akar krisis identitas budaya di Indonesia. Pertama adalah konsep identitas itu sendiri yang tidak pernah menjadi sesuatu yang absolut dan permanen. Berikutnya adalah kebijakan budaya terkait politik kebudayaan dari setiap rezim yang berkuasa di Indonesia. Sementara yang terakhir tentu saja akibat invasi kapitalisme global yang memberikan banyak sekali celah ambiguitas pada pengembangan dan pembentukan identitas budaya nasional. 
Akar krisis pertama adalah konsep identitas yang memiliki banyak problematika. Konsep mengenai identitas membawa masalahnya sendiri ketika dijabarkan dan dimaknai. Identitas secara sederhana dimaknai sebagai segala sesuatu yang membedakan seseorang dengan yang lainnya. Frase "segala sesuatu" bertendensi pada sifat yang plural dan dinamis. Stuart Hall bahkan memberi tekanan pada konsep identitas sebagai sesuatu yang tidak pernah sempurna, selalu dalam proses, dan selalu dibentuk dari dalam (Rutherford, 1990: 222). Kondisi ini berjalan beriringan dengan proses pembentukan identitas nasional Indonesia yang juga masih jauh dari kata selesai.

Amin Maalouf (2004) dalam catatannya menyebut bahwa identitas bekerja melalui krisis. Hal ini senada dengan Yasraf Amir Piliang (2010: 367) yang mengatakan bahwa identitas hanya akan menjadi sebuah isu tatkala ia berada dalam situasi krisis. Seorang manusia yang merupakan entitas dari sebuah kelompok membangun identitasnya dengan cara yang sangat kompleks. Identitas ditenggarai sebagai sebuah silang-menyilang afiliasi nilai dan internalisasi yang terbangun selama hidup seseorang. Amin Maalouf meyakini tidak ada identitas yang bersifat tunggal melainkan bersifat dominan atau sub-ordinat. Sebagai contoh, seseorang dapat memiliki identitas dalam dirinya sekaligus sebagai seorang Sunda, Muslim, Indonesia, bahkan Jakmania (kelompok suporter klub sepakbola Persija).

Semua identitas tersebut bisa berada dalam waktu bersamaan dalam diri seseorang dan menjadi dominan tatkala dihadapkan pada krisis. Sebagai contoh, ketika identitas seseorang sebagai suporter Persija (Jakmania) tengah menghadapi krisis dengan suporter Persib Bandung (Viking), maka ia akan menjadi
Jakmania yang fanatik. Identitasnya sebagai seorang Jakmania menjadi dominan dibandingkan identitasnya yang lain. Pada saat itulah, dia bisa saja menyerang kelompok yang sebenarnya memiliki banyak irisan identitas dengannya. Ia bisa saja menyerang seseorang yang sama-sama beragama Islam, bersuku Sunda, dan berkewarganegaraan Indonesia.

Pada kesempatan yang lain, bisa jadi kelompok yang pernah ia serang dalam konteks fanatisme suporter sepakbola menjadi saudara seperjuangan-nya ketika identitas mereka yang beriris-an sama-sama menghadapi masalah (krisis). Misalnya, seorang anggota Jakmania bisa tiba-tiba bergabung bersama anggota Viking dalam demonstrasi menolak penistaan agama. Seperti yang terlihat pada demonstrasi besar tanggal 2 Desember tahun 2016. Saat itu, sekitar tujuh juta umat Islam dari berbagai latar belakang hadir di Jakarta dalam demo menolak penistaan agama. Hal-hal semacam ini akan terus-menerus berlangsung dalam hidup seseorang dan secara kolektif di tengah masyarakat dengan intensitas yang beragam.

Dalam ranah kebudayaan, identifikasi etnis seseorang akan menjadi bias ketika ia masuk ke ruang publik yang plural seperti kota-kota besar. Konflik dan perselisihan yang didasarkan pada identitas kesukuan akan melemah dengan sendirinya ketika pluralitas dimampatkan dalam ruang publik yang sama dan terbatas. Ditambah lagi, tekanan gaya hidup masyarakat urban yang kurang memberikan celah representasi identitas etnis bagi para anggotanya. Saat eksistensi identitas budaya tradisional mulai terpinggirkan dan tereduksi, saat itulah identitas juga masuk ke situasi krisis.

Akar krisis yang kedua adalah kebijakan budaya yang dipraktikkan oleh rezim penguasa. Secara khusus, hal ini 
diulas oleh Tod Jones (2015) dalam bukunya yang berjudul Kebudayaan dan Kekuasaan di Indonesia. Dalam bukunya itu, Jones memaparkan berbagai politik kebudayan di Indonesia yang secara sengaja diterapkan sesuai kepentingan politis setiap rezim yang pernah berkuasa. Benang merah dari setiap rezim penguasa ini adalah keingingan untuk membentuk identitas budaya nasional dalam semangat keberagaman.

Politik kebudayaan yang dijalankan oleh setiap rezim penguasa di Indonesia berakar pada konsep pembentukan negara-bangsa yang ada di Eropa. Sejak pecahnya Revolusi erancis, proses pembentukan negara-bangsa yang baru di Eropa adalah proses homogenisasi kultural dan bukan rasial. Menurut T.K. Oommen (2009: 207), sebuah bangsa haruslah menjadi bangsa yang homogen untuk mendapatkan pemerintahan yang efektif. Namun, di sisi lain, ide homogenisasi yang dikemas dalam wacana nasionalisme seperti di Indonesia bisa menjadi alat pemusnah identitas budaya daerah. Hal ini diperkuat oleh pendapat Furnivall yang dikutip T.K. Oommen (2009: 208) yang mengatakan bahwa nasionalisme pada masyarakat yang plural adalah sebuah kekuatan pengacau yang cenderung memecah belah dan bukan mengonsolidasi tatanan sosial.

Wujud homogenisasi kultural yang paling terasa di Indonesia adalah penetapan bahasa Indonesia sebagai bahasa resmi negara. Hal ini kontras dengan yang terjadi di Eropa seperti Inggris dan Prancis. Di kedua negara tersebut, bahasa resmi negara dipilih dari bahasa yang paling banyak dituturkan oleh masyarakat mereka. Dalam kasus Indonesia, bahasa Indonesia justru menjadi bahasa asing bagi sebagian besar masyarakat ketika ia diperkenalkan. Bahasa Indonesia telah menyebabkan hilangnya sebagian besar bahasa daerah di Indonesia (Oommen, 2009: 227). Padahal, bahasa adalah alat identifikasi utama sebuah kebudayaan karena ia adalah unsur yang membedakan satu kebudayaan dengan kebudayaan lainnya. Rusak dan lestarinya sebuah bahasa, menjadi penanda status eksistensi identitas kebudayaan tersebut.

Proses pembentukan kebudayaan nasional itulah yang justru menjadi akar krisis identitas budaya. Diversitas kebudayaan yang sangat tinggi di Indonesia membuat proses pemilah-milahan budaya daerah untuk diangkat menjadi budaya nasional menjadi seperti politik belah bambu. Menurut T.M. Dhani Iqbal (2014), politik belah bambu dalam kebudayaan adalah mengangkat satu kebudayaan dan menginjak kebudayaan yang lain dalam waktu bersamaan. Hal ini sangat terlihat pada fenomena "Jawanisasi" yang terjadi pada beragam aspek pembentukan identitas nasional. Misalnya, penamaan tanggal 2 Oktober sebagai hari batik nasional yang merupakan contoh teraktual fenomena ini. Alih-alih menggunakan termin "kain tradisional", pemerintah pusat justru memilih kata "batik" yang berkonotasi pada kain tradisional masyarakat suku Jawa. Padahal di luar suku Jawa, kain tradisional memiliki nama yang beragam, seperti ulos (Batak), songket (Palembang), sasirangan (Kalimantan Selatan), tapis (Lampung), dan lain-lain.

Contoh lainnya adalah peminggiran sistem religi yang ada pada etnis-etnis minor. Sistem religi adalah salah satu unsur utama yang membentuk identitas sebuah kebudayaan. Ironisnya, bentuk negara kesatuan yang sentralistik hanya menyediakan enam pilihan agama resmi sebagai bagian dari identitas warga negara. Sistem religi atau agama di luar enam agama tersebut akan dilebur atau dilenyapkan sama sekali dalam sistem administrasi nasional. Dengan kata lain, negara tidak mengakui dan tidak 
memberikan pelayanan yang seharusnya pada praktik peribadatan agama-agama minor.

Merujuk pada sistem religi Kaharingan yang dianut sebagian masyarakat etnis Dayak, yang tidak diakui oleh pemerintah pusat. Pada akhirnya, untuk mendapatkan pelayanan yang setara dengan warga negara lain, mereka harus mengisi data identitas mereka dengan memilih salah satu dari enam agama yang diakui. Hal semacam ini menjadi ironi di tengah semangat pembentukan identitas nasional yang berbasiskan budaya daerah. Pembiaran dan pelestarian sistem semacam ini akan membuat identitas masyarakat Dayak tergerus dan pada gilirannya akan musnah.

Terkait politik identitas kebudayaan daerah, konstitusi formal di Indonesia bahkan melemahkan identitas masyarakat adat dengan mencabut kewenangan lembaga pemerintahan adat untuk menjalankan fungsinya. Meski lahir kebijakan otonomi daerah, kewenangan lembaga pemerintahan adat tetap tidak dikembalikan. Tidak hanya sampai di situ, negara juga tidak mengakui kepemilikan tanah adat yang selama ini menjadi ruang kultural independen dari kebudayaan daerah. Dalam logika hukum formal di Indonesia, semua lahan di komunitas lokal adalah milik negara (Acciaioli dalam Davidson, 2009: 338-339). Pada gilirannya, hal ini menjadi celah untuk terbitnya konsesi oleh pemerintah daerah yang ujungnya adalah pintu masuk para pengusaha untuk melakukan eksploitasi sumber daya alam dan tentu saja budaya.

Akar krisis yang ketiga adalah invasi kapitalisme global yang tidak bisa dielakkan. Kapitalisme global atau yang dalam bahasa Yasraf Amir Piliang (2010) disebut sebagai kapitalisme muktahir adalah inti perasan dari termin globalisasi. Ancaman eksistensi tradisi dan kebudayaan lokal sangat sering diarahkan pada globalisasi yang dalam pandangan banyak pakar membawa sifat hegemoni dan fasis. Globalisasi juga menjadi penanda era pos-modernisme yang menggeser semua makna konsumsi, termasuk di dalamnya kode-kode estetika dari seni visual.

Kapitalisme global ini memunculkan apa yang disebut sebagai masyarakat post-industri dan kebudayaan postmodern. Ciri utama dari masyarakat postindustri adalah budaya konsumerisme yang menggeser makna konsumsi dari pemenuhan fungsi utilitas menjadi penanda kelas (simbolik) dan status sosial. Sedangkan postmodern sering dikaitkan dengan kondisi masyarakat ketika gaya hidup konsumer dan konsumsi massa mendominasi cita rasa dan gaya. Postmodernisme dengan demikian merupakan suatu era baru perkembangan kapitalisme akhir dan masyarakat kontemporer (Sugihartati, 2014: 136).

Setidaknya, ada tiga kekuasaan yang beroperasi di atas budaya konsumerisme yang muncul di era postmodern ini, yaitu kekuasaan kapital, produser, dan media massa. Para sarjana dari mazhab Frankfurt menyebut relasi tiga kekuasaan itu sebagai totalitarian dan fasis karena ada pengaturan massa (konsumer) dari atas (produser) (Piliang, 2010: 146). Trilogi kekuasaan itulah yang beroperasi di belakang penciptaan produk-produk budaya populer saat ini. Produk budaya populer meliputi seluruh produk kebudayaan yang diciptakan secara massal dan komersial (Heryanto, 2015: 22).

Postmodernisme dan konsumerisme adalah wacana yang kerap muncul dalam diskursus globalisasi. Secara sederhana, globalisasi bisa diartikan sebagai proses menjadikan dunia ke dalam satu tatanan (order). Satu tatanan yang dimaksud adalah semua tata 
nilai yang datang dari kekuatan-kekuatan budaya superior atau koalisi di antara mereka. Tatanan nilai itu bisa mewujud dalam etika dan estetika. Semua hal tersebut bertendensi ancaman terhadap kebudayaan lokal. Secara radikal, Amin Maalouf (2004: 115) bahkan menyebutkan bahwa sifat hegemonik dari globalisasi akan melahirkan dua bahaya besar. Pertama adalah musnahnya secara bertahap berbagai bahasa, tradisi, serta kebudayaan. Sementara yang kedua adalah dipeluknya sikap-sikap radikal atau bunuh diri oleh budaya-budaya yang terancam.

Memahami status terancamnya sebuah kebudayaan lokal di tengah era globalisasi bisa dilihat dari contoh bagaimana tari cokek betawi bertahan saat ini. Tari tradisional seperti tari cokek dilestarikan secara turun-temurun dari generasi ke generasi. Sementara saat ini, generasi muda Betawi harus menyandingkan tari cokek dengan tari modern seperti break dance. Hegemoni media yang memperkenalkan break dance sebagai aktivitas masyarakat urban yang modern dan kekinian tidak bisa dihindari. Globalisasi membungkus break dance dengan istilah-istilah seperti; keren, gaya, dan gaul. Semua hal itu beririsan dengan kepentingan bisnis para kapitalis media untuk mendapatkan rating setingi-tingginya. Di sisi lain, tari cokek tetap berada di sanggar-sanggar kesenian daerah, jauh dari peliputan media dan pengemasan estetik komersial layar kaca.

Kebijakan yang bersifat top

down dari pemerintah pusat ke masyarakat untuk melindungi kebudayaan daerah mutlak diperlukan di era globalisasi. Seperti halnya kasus tari cokek, praktik, dan aktualisasinya harus diinisiasi langsung oleh otoritas penguasa. Jika tidak ada peran pemerintah dalam usaha konservasi budaya ini, niscaya masyarakat akan mengikuti mekanisme pasar yang tersedia. Hal itu sama saja dengan membebaskan seorang pemuda Betawi untuk memilih antara menonton pagelaran tari cokek atau break dance. Kecenderungan pilihan dari sang pemuda Betawi itu tentu saja mudah ditebak. Hasil dari mekanisme pasar bebas itu tentu saja akan melenyapkan preferensi masyarakat terhadap budaya tradisional mereka.

\section{Studi Poskolonialisme pada Produk Desain}

Krisis identitas yang melanda negara bekas jajahan seperti Indonesia terjadi dengan kontraksi serta intensitas yang tinggi. Situasi itu diperparah dengan bentuk negara kesatuan yang telah disepakati dan dipertahankan dari rezim ke rezim mulai masa kemerdekaan sampai hari ini. Dalam perjalanan sejarah, sistem ekonomi kapital juga telah memenangi pertarungan yang penuh darah dengan sosialisme total yang pernah diusung partai komunis. Sampai pada masa reformasi, sistem ekonomi kapital berbasis pasar bebas menjadi corak dominan yang dipraktikkan di Indonesia.

Wacana kapitalisme muktahir yang sering kali disebut sebagai era neoliberalisme ekonomi memberikan asumsi pada para pemikir ilmu sosial bahwa era kolonial justru memasuki zaman baru. Penjajahan yang secara formal politis telah berakhir ternyata terus dilanjutkan dengan bentuknya yang baru terutama pada sistem ekonomi dan tentu saja kebudayaan.

Jika kita mengacu terlebih dahulu pada definisi dari Oxford English Dictionary, maka kolonialisme berasal dari bahasa latin "colonia" yang berarti "tanah pertanian" atau "pemukiman". Kata ini mengacu kepada orang Romawi yang bermukim di negeri-negeri lain, tetapi masih mempertahankan kewarganegaraan mereka (Loomba, 2016: 1). Kemudian, definisi tersebut dikonteks- 
tualisasikan menjadi penaklukan dan penguasaan atas tanah dan harta benda rakyat lain. Pada level ini, kolonialisme masih berada dalam tahap pra-kapitalis menurut pemikiran Marxis karena pada tahap selanjutnya, kolonialisme tidak hanya mengambil kekayaan negara lain, melainkan mengubah struktur perekonomian mereka. Kolonialisme modern yang kapitalis, menarik bangsabangsa jajahan ke dalam hubungan yang kompleks dengan negara induk, sehingga terjadi arus manusia dan sumber daya alam antara negara koloni dengan negaranegara kolonialnya (Loomba, 2016: 5).

Kolonialisme tidak pernah benarbenar hilang dari muka bumi ketika sistem kapitalisme global justru dilahirkan karenanya. Menurut Lenin dalam bukunya yang berjudul Imperialism: The Highest State of Capitalism (1947), negara-negara kapitalis kolonial akan mengekspansi koloni mereka untuk memperpanjang umur kapitalisme di negara mereka. Negara-negara koloni tersebut tidak akan benar-benar "dibebaskan" dalam arti tetap dijadikan pemasok bahan baku industri, pekerjapekerja murah, dan sekaligus pasar yang potensial. Situasi ketergantungan negaranegara bekas jajahan ini yang sering disebut sebagai era neo-kolonial/neoimperial.

Ania Loomba (2016: 8-9) membahas lebih jauh mengenai ambiguitas istilah kolonialisme yang dipahami saat ini. Menurutnya, kolonialisme memiliki dua konotasi besar yaitu politis dan ekonomis. Jika mengacu pada konotasi politis, kolonialisme bisa dinyatakan berakhir ketika negara koloni mendapatkan kemerdekaan secara formal dari pemerintah kolonial. Namun, jika kolonialisme dimaknai sebagai penetrasi ekonomi dan kendali atas pasar, maka perubahan status politik tidak akan mengubah situasi secara mendasar. Dengan pengertian seperti itu, termin pos (pasca) pada frase poskolonial tidak bermakna tunggal sebagai masa/periode melainkan juga sebagai wacana.

Sependapat dengan Loomba, Jorge de Alva (1995: 243) menegaskan kondisi pasca-penjajahan yang tidak bisa begitu saja disebut poskolonial. Menurutnya, struktur sosial masyarakat baru setelah era penjajahan bahkan juga menciptakan hierarki politik dan ekonomi. Terdapat lapisan dalam masyarakat negara-bangsa yang baru ini yang pada gilirannya menentukan akses terhadap kekuasaan politik. Maka, mereka yang secara struktur sosial berada di lapisan paling bawah dalam hierarki kekuasaan, sejatinya tidak pernah mengenal kata 'pasca'-kolonial. Mereka inilah yang dalam pandangan Gayatri Spivak sering disebut sebagai kelompok subaltern.

Wacana poskolonialisme semakin mengemuka ketika Edward Said (1978) menelurkan karya fenomenalnya yang berjudul Orientalisme. Pada karyanya itu, Said memberi penegasan bahwa kerjakerja kolonial yang melahirkan para orientalis telah menghasilkan citra yang sangat rasis pada hubungan Barat dan Timur. Pihak Barat sebagai kekuatan kolonial memiliki dominasi untuk mendeskripsikan siapa Barat dan siapa Timur. Pola relasi antara Barat dan Timur selalu dilihat dalam posisi yang biner dan sekaligus bias. Jika Barat adalah modern, maka Timur adalah terbelakang. Jika Barat rasional, maka Timur irasional, dan seterusnya. Cara pandang dan paradigma seperti ini terus dilestarikan bahkan setelah masa-masa penjajahan fisik selesai (kemerdekaan). Sistem pengetahuan para orientalis telah mengunci dunia Timur untuk tetap pada inferioritas mereka sembari kapitalisme global memastikan keuntungan tetap mengalir ke negara Barat.

Cara pandang Edward Said ini kemudian dikritik oleh pemikir lainnya seperti Ania Loomba dan Homi Bhabha. 
Menurut keduanya, penempatan relasi Barat dan Timur dalam posisi biner dianggap terlalu kaku dan mengabaikan beragam dinamika interaksi kultural yang terjadi. Budaya dominan dari Barat, tidak selamanya mengatur dan membentuk identitas budaya Timur secara hirarkis melainkan memunculkan apa yang disebut Bhabha sebagai ruang ketiga/liminal, atau hibriditas.

Hibriditas dalam pandangan Bhabha merupakan sebuah bentuk silang budaya atau perselingkuhan budaya antara budaya dominan dengan budaya yang terhegemoni. Pada pengertian lain, hibriditas juga bisa diartikan sebagai perlawanan terhadap budaya dominan. Jika ditarik ke era globalisasi seperti hari ini, hibridisasi pada produk-produk desain merupakan bentuk perlawanan terhadap budaya dominan yang dalam hal ini datang dari peradaban Barat. Hibdridisasi adalah sebuah keniscayaan di tengah hegemoni budaya Barat yang juga telah memunculkan budaya konsumerisme.

Konsep lain dari Homi Bhabha setelah hibriditas adalah mimikri yang diartikan secara sederhana sebagai "peniruan" seperti yang dilakukan beberapa jenis hewan di alam liar untuk bertahan hidup. Mimikri dalam konteks kebudayaan adalah penyelarasan identitas antara budaya penjajah dengan yang terjajah. Penyelarasan ini tidak diartikan sebagai ketundukan pihak terjajah, melainkan sebuah perlawanan subversif terhadap penjajahan itu sendiri. Dengan demikian, mimikri adalah kerjakerja dalam kerangka interaksi budaya yang menghasilkan hibriditas kebudayaan.

Sebagai contoh, di Tenggarong, Kabupaten Kutai Kartanegara, Provinsi Kalimantan Timur, muncul sebuah kelompok musik metal bernama Kapital yang mendesain sampul album mereka dengan beragam ornamen Dayak. Kelompok musik ini mengambil genre metal sebagai medium penyampaian pesan mereka kepada khalayak. Hibriditas terlihat ketika unsur budaya Dayak yang berupa ornamen lokal tampak pada sampul album musik bergenre metal tersebut.

Pola analisis poskolonial dalam kasus sampul album Kapital tentu saja relasi tanda antara musik metal dengan kebudayaan Dayak. Musik metal adalah produk budaya dominan di era kapitalisme muktahir. Ia datang dari Barat dan diterima sebagai komoditas industri seni urban dan produk budaya populer. Di sisi lain, kebudayaan Dayak dengan segala tata nilai dan artefaknya tergolong dalam kelompok subaltern jika mengacu pada teori Gayatri Spivak. Oleh sebab itu, penggunaan ornamen khas budaya Dayak seperti topeng khas Dayak dalam sampul album musik metal merupakan wujud hibriditas budaya. 


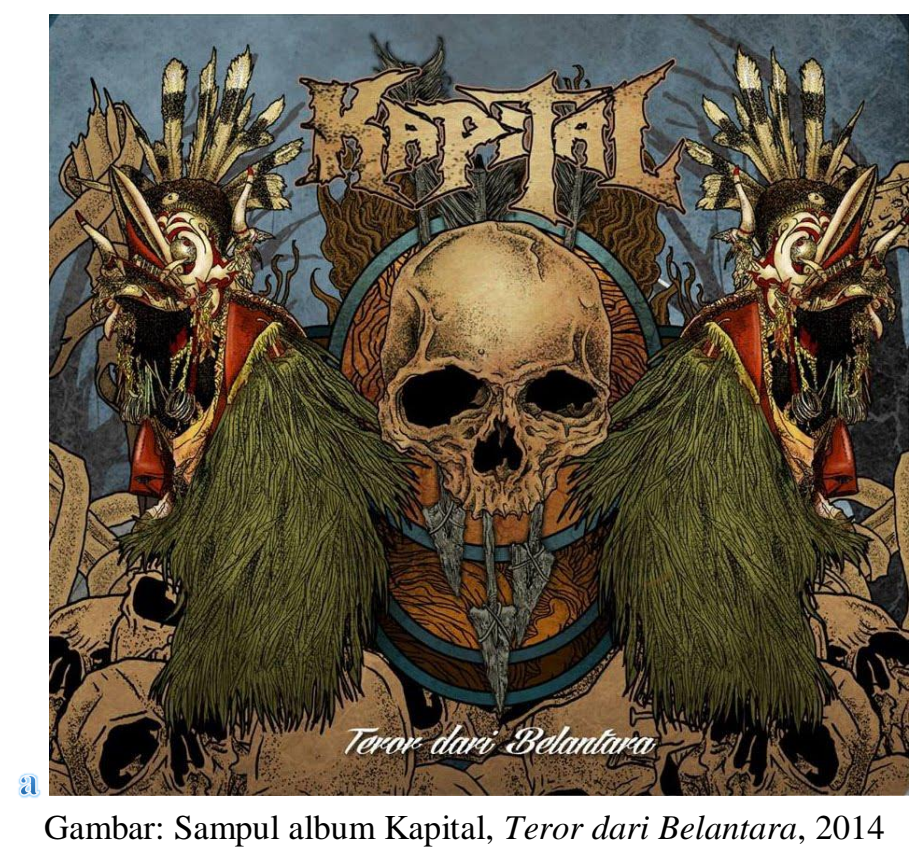

Dalam sampul album tersebut, umumnya. Di belakang tengkorak tersebut, pada sisi kanan dan kiri, terdapat terlihat ilustrasi tengkorak yang memiliki makna kedamaian bagi masyakarat Dayak. Jika dikaji secara semiotik, terjadi pertukaran tanda terkait pemaknaan tengkorak bagi masyarakat Dayak dan khalayak pendengar musik metal pada ilustrasi kostum dan properti penari hudoq yang merupakan tradisi khas masyarakat sub-etnis Dayak di Kalimantan Timur.

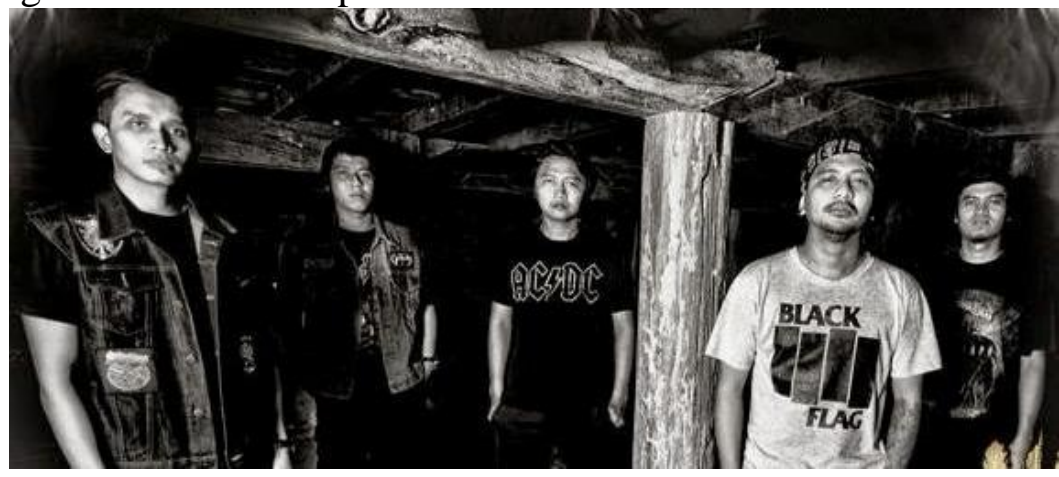

Gambar: Bagian dalam sampul album Kapital dengan latar belakang rumah lamin

Penempatan konten identitas budaya yang bersifat hibrid juga tampak pada sampul album bagian dalam. Para personil grup musik Kapital berpose dengan latar bagian bawah rumah adat Dayak yang disebut Lamin. Selain itu, daftar isi lagu dalam album Kapital ini juga memuat konten kearifan lokal masyarakat Dayak. Alat musik tradisional Dayak yang bernama sampeq ikut dimainkan dan dijadikan judul lagu dalam album ini. Metode ini mengulang kesuksesan yang dilakukan oleh band Burgerkill dari Bandung yang juga melakukan hibrididsasi budaya. Komunitas pemusik metal di Bandung, terutama band Burgerkill dianggap telah menyelamatkan alat musik tradisional Sunda yang bernama karinding yang sebelumnya terancam punah. Joel S. Kahn (2016: ix) menyebut fenomena ini sebagai gejala kulturisasi era postmodern 
yang ditandai dengan beragam penyajian lokalitas tetapi tetap berada dalam sistem kontrol dunia.
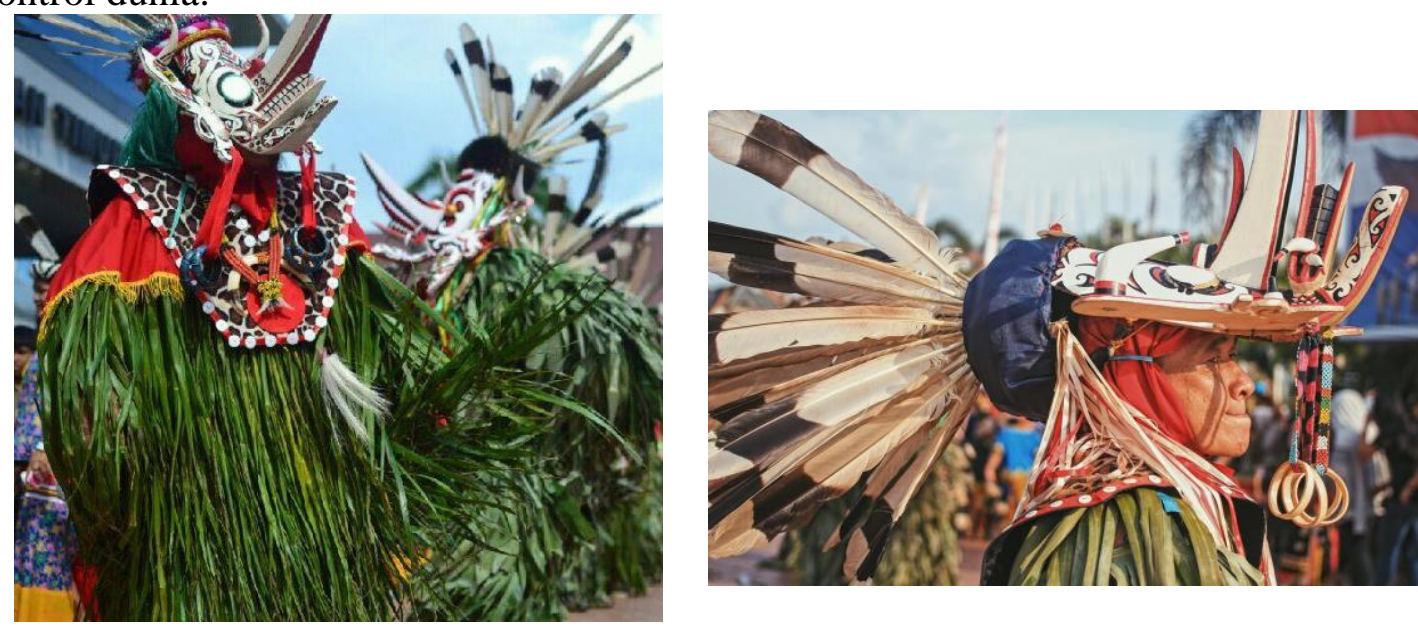

Gambar: Ritual tari Hudoq Dayak Bahau, Kalimantan Timur

Sumber: www.tinypic.com dan www.sanggarnusantaradotcom.blogspot.com

Penggarapan sampul album Kapital juga merupakan bentuk mimikri yang bertendensi pada perlawanan terhadap budaya dominan sekaligus wahana bertahan hidup. Perlawanan terhadap budaya dominan terwujud pada penggunaan ilustrasi tengkorak yang memiliki spektrum makna yang kontras dengan khalayak universal pendengar musik metal. Tengkorak umumnya diasosiasikan kepada hal-hal yang bersifat horor, seram, mistik, dan tragis. Namun, bagi masyarakat Dayak, tengkorak justru simbol kedamaian karena keyakinan mereka terhadap kehidupan pasca kematian yang berarti kedamaian abadi. Dalam ritual kematian masyarakat Dayak, jenazah yang baru meninggal dikuburkan untuk sementara saja. Kuburan ini kemudian akan dibongkar kembali dan pihak keluarga akan mengambil serta menyusun ulang tulang-belulang si mayat untuk kemudian dikuburkan kembali secara permanen. Ritual penyusunan tulang-belulang ini diyakini sebagai sebuah kewajiban yang apabila tidak dilakukan, maka akan membuat roh dari orang yang meninggal tersebut gentayangan menganggu manusia yang hidup. Dengan demikian, tengkorak menandakan selesainya kewajiban kerabat jenazah untuk melepaskan roh ke alamnya dan menemui kedamaian abadi.

Contoh lain dari fenomena hibriditas ini adalah kasus penciptaan logo rumah makan Pecel Lele Lela pada tahun 2011. Hibridisasi yang terjadi dilakukan melalui kerja mimikri terhadap logo Starbucks Coffee Company yang merupakan perusahaan waralaba internasional. Dalam ranah keilmuan desain komunikasi visual, penciptaan logo komersial merupakan proses kreatif yang melibatkan banyak kepentingan. Logo Pecel Lele Lela saat itu jelas merupakan sebuah mimikri dari logo Starbucks yang menjadi simbol peradaban modern hari ini. Starbucks adalah kedai kopi bertaraf internasional yang memiliki banyak sekali cabang di kota-kota besar dunia. Sebaliknya, makanan berupa pecel lele adalah khasanah kuliner tradisional Jawa Timur yang sama sekali belum bisa dikategorikan mendunia. 

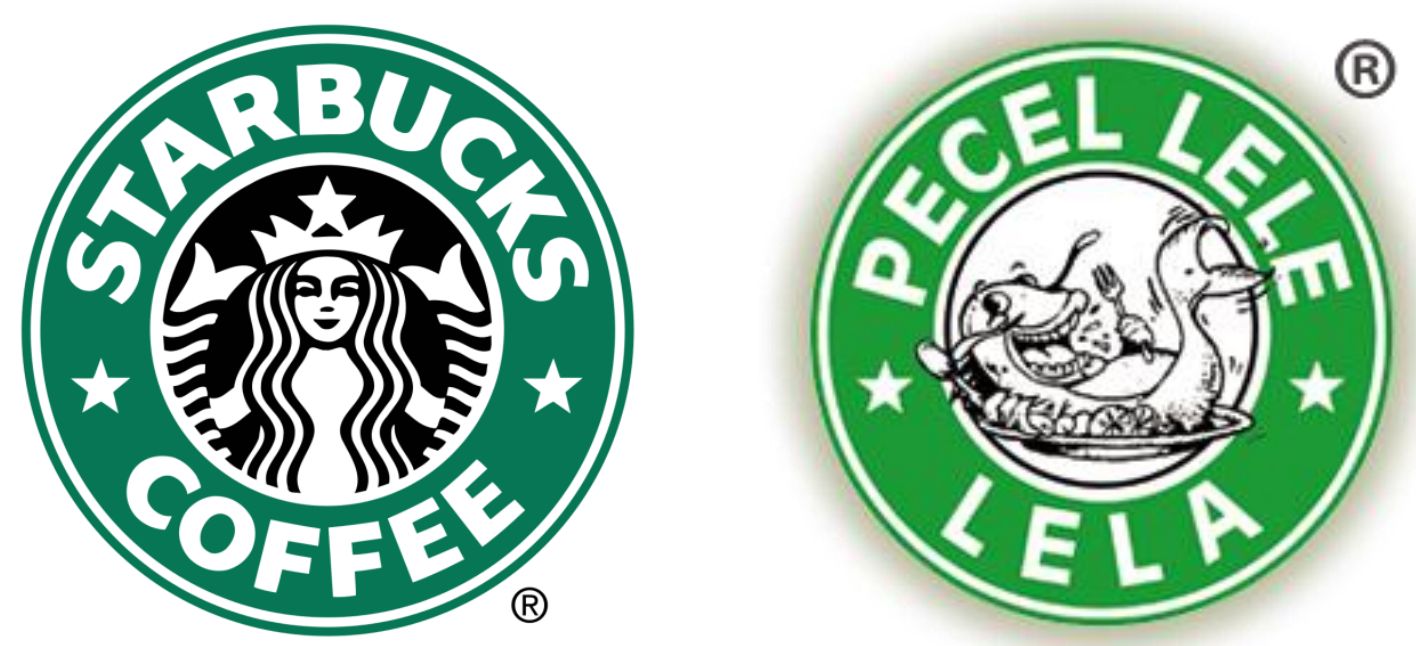

Gambar: Mimikri pada logo Starbucks Coffee Company oleh Pecel Lele Lela, 2012

Mimikri logo pada Pecel Lele Lela melahirkan hibriditas budaya yang sangat jelas bertendensi pada upaya mengangkat identitas budaya lokal di tengah era perdagangan bebas. Pecel lele yang merupakan kuliner khas Jawa Timur diperkenalkan ke seluruh dunia melalui perusahaan bernama Pecel Lele Lela. Dalam laman web resmi mereka tertulis tagline sederhana dan lugas "Bersama Kami Pecel Lele Telah Mendunia" (www.lele-lela.com, diakses $25 \mathrm{Mei}$ 2017). Hal tersebut jelas menyiratkan visi perusahaan untuk mengangkat identitas budaya lokal ke taraf internasional.

Namun, kerja mimikri Pecel Lele Lela ini direspon negatif oleh Starbucks Coffee Company. Melalui kuasa hukum mereka pada tahun 2014, Starbucks menggugat Pecel Lele Lela karena dianggap telah meniru logo perusahaan mereka. Gugatan tersebut berhasil memaksa Pecel Lelel Lela untuk mengganti dan mengubah desain logo mereka. Pada akhirnya, Rangga Umara selaku pemilik perusahaan Pecel Lele Lela bersedia menyanggupi perubahan desain logo yang tidak lagi meniru logo kedai kopi Starbucks (www.bisniskeuangan.kompas.com, diakses 24 Mei 2017).

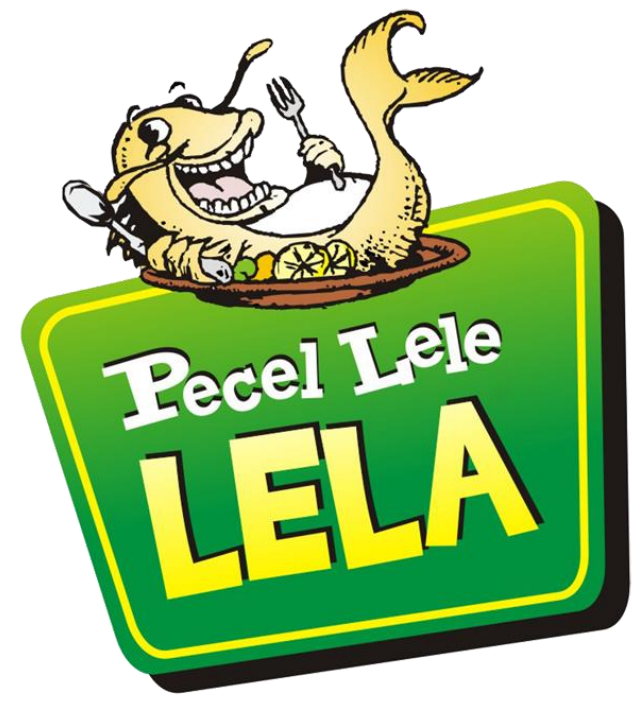

Gambar: Logo Pecel Lele Lela pascagugatan dari Starbucks

Sumber: www.lele-lela.com

Fenomena mimikri pada Pecel Lele Lela tahun 2011 merupakan bentuk perlawanan dari hegemoni budaya dominan. Meski pada akhirnya kalah dalam gugatan di pengadilan, fenomena tersebut membuktikan bahwa sistem ekonomi berbasis pasar bebas di era kapitalisme global merupakan bentuk penjajahan gaya baru. Melalui instrumen seperti perlindungan hak kekayaan 
intelektual dan lain-lain, kapitalisme global telah memberi proteksi pada kepentingan ekonomi budaya dominan di negara-negara bekas terjajah. Ketika gaya visual logo Pecel Lele Lela meniru Starbucks, saat itulah terjadi pengakuan hegemoni budaya Barat sekaligus ejekan terhadapnya. Hal ini selaras dengan pendapat Homi Bhabha yang mengatakan bahwa kerja peniruan (mimikri) memiliki tendensi mengakui keunggulan budaya yang ditiru sekaligus juga mengejeknya (Bhabha, 1994: 115).

\section{SIMPULAN}

Kerja-kerja kolonial terhadap bangsa bekas terjajah seperti Indonesia ternyata belum berakhir sekalipun kemerdekaan politis telah diraih. Teoritoeri poskolonial telah banyak dipakai untuk memahami dan mengurai situasi pelik konteks penjajahan baru di era globalisasi. Proyek pembentukan identitas nasional yang diharapkan mengakomodasi kepentingan lokalitas budaya ternyata masuk dalam situasi krisis. Hal ini diperparah dengan politik kebudayaan di Indonesia yang justru memarjinalkan banyak identitas budaya daerah. Selain itu, krisis identitas budaya yang hari ini sering diulas dan dianalisis oleh banyak sarjana ternyata memiliki banyak faktor pemicu. Salah satu faktor dominan penyebab krisis identitas ini adalah kapitalisme global yang telah melahirkan budaya konsumerisme. Inilah penanda era penjajahan di zaman modern.

Menurut Edward Said (2010: 507508), konsumerisme di dunia Timur telah menjadi katalis bagi Barat untuk menancapkan hegemoni mereka. Said menjelaskan fenomena tersebut sebagai salah satu faktor keberhasilan proyek orientalisme di dunia Timur. Jika Barat hanya mengambil dari Timur sumber daya ekonomis material, Timur justru mengambil seluruh materi dan ideologi dari Barat. Implikasinya adalah perubahan cara pandang dan selera masyarakat Timur terhadap segala sesuatu yang terkait modernisasi. Terjadi pembakuan cita rasa besar-besaran di dunia Timur, bahkan terhadap citra ke-Timuran itu sendiri yang disuplai oleh media masa Barat. Di sisi lain, kelompok akademis Timur yang sudah ter-Baratkan kerap mendukung dan melegitimasi gagasangagasan modernisasi serta kemajuan yang role modelnya adalah Amerika Serikat. Dengan kata lain, semakin konsumtif masyarakat kelas menengah sebuah negara, semakin terancam pula identitas budaya yang sedang direkonstruksi.

Oleh karena itu, sebuah perancangan produk desain hari ini harus menyadari sepenuhnya situasi krisis identitas budaya yang sedang terjadi. Teori poskolonialisme yang digagas Homi Bhabha seperti hibriditas dan mimikri merupakan alat bantu pengurai masalah ini. Menurut Epafras (2012: 7), hibriditas dan mimikri bisa menjadi wahana untuk bertahan hidup sekaligus perlawanan terhadap budaya dominan. Pernyataan ini senada dengan Ikwan Setiawan yang mengatakan bahwa konsep ruang ketiga milik Bhabha (mimikri dan hibriditas) membuat masyarakat bekas terjajah mampu melanjutkan tradisi lokal sekaligus mengambil dari yang Barat, tetapi tidak sepenuhnya. Menurut Ikwan, hal ini merupakan bentuk kesadaran politik untuk tidak menolak yang Barat sekaligus tidak melupakan yang lokal. Dengan kesadaran semacam inilah kemandirian dan budaya masyarakat lokal akan terus berlanjut dalam konteks zaman yang selalu bertransformasi, sekaligus melakukan resistensi terhadap pengaruhpengaruh reduktif budaya luar (Setiawan, 2016: 4).

Seorang desainer komunikasi visual sejatinya bisa menjadi agen kebudayaan untuk membangun identitas 
hibrid yang bertendensi melestarikan kebudayaan lokal. Mereka juga bisa menjadi semacam juru bicara bagi kelompok subaltern seperti masyarakat Dayak dan beragam kelompok etnis di Indonesia. Keilmuan desain komunikasi visual menyediakan beragam produk perancangan seni visual yang bisa memuat konten serta profil kebudayaan masyarakat adat dengan kemasan media yang kekinian. Meski tidak menjadi satusatunya solusi pelestarian budaya, perancangan produk desain komunikasi visual semacam itu bisa menjadi sarana yang sama efektifnya dengan riset-riset antropologis terkait kebudayaan. Lebih dari itu, produk-produk desain komunikasi visual justru bisa menjangkau khalayak yang lebih luas dan beragam dibandingkan produk penelitian antropologi yang hanya diakses secara terbatas oleh kalangan akademisi.

\section{DAFTAR PUSTAKA}

\section{Buku}

Alva, J.J.K. de. (1995). "The Postcolonialization of The Latin American Experience: A Reconsideration of 'Colonialism', 'Postcolonialism', and 'Mestizaje"” dalam G. Prakash (ed.). After Colonialism, Imperial Histories, and Postcolonial Displacements. Princenton: Princenton University Press.

Bhabha, H.K. (1994). The Location of Culture. London: Routledge.

Davidson, J.S (ed). (2010). Adat Dalam Politik Indonesia. Jakarta: Yayasan Pustaka Obor IndonesiaKITLV Jakarta.

Heryanto, A. (2015). Identitas dan Kenikmatan: Politik Budaya Layar Indonesia. Jakarta: Kepustakaan Populer Gramedia.
Iqbal, T.M.D. (2014). Toleransi dan Perkauman: Keberagaman Dalam Perspektif Agama-Agama dan Etnis-Etnis. Jakarta: Lentera Timur.

Jones, T. (2015). Kebudayaan dan Kekuasaan di Indonesia: Kebijakan Budaya Selama Abad ke-20 Hingga Era Reformasi. Jakarta: Yayasan Pustaka Obor Indonesia-KITLV Jakarta.

Kahn, J.S. (2016). Kultur, Multikultur, Postkultur: Keragaman Budaya dan Imperialisme Kapitalisme Global. Yogyakarta: Institute of Nation Development Studies.

Kumar, M. (2000). "Postcolonial Theory and Cross-Culturalism: Collaborative 'Signposts' of Discursives Pratice." Journal of Educational Enquiry. Vol 1 No.2. University of South Australia.

Loomba,

A. (2016). Kolonialisme/Pascakolonialisme. Yogyakarta: Narasi-Pustaka Promethea.Maalouf, A. 2004. Atas Nama Identitas. Yogyakarta: Resist Book.

Oommen,

T.K. (2009).

Kewarganegaraan, Kebangsaan, dan Etnisitas: Mendamaikan Persaingan Identitas. Bantul: Kreasi Wacana.

Piliang, Y.A. (2010). Dunia Yang Dilipat: Tamasya Melampaui Batas-Batas Kebudayaan. Bandung: Matahari.

Rutherford, J. (1990). Identity: Community, Culture, Difference. London: Lawrence \& Wishart.

Said, E.W. 2010. Orientalisme: Menggugat Hegemoni Barat dan Mendudukkan Timur Sebagai Subjek. Yogyakarta: Pustaka Pelajar. 
Sugihartati, R. (2014). Perkembangan Masyarakat Informasi dan Teori Sosial Kontemporer. Jakarta: Kencana.

Setiawan, I. (2016). Hibriditas Budaya dalam Lintasan Perspektif. http://matatimoer.or.id/wpcontent/uploads/2016/12/Hibridit as-budaya-dalam-lintasanperspektif.pdf

Epafras, L.C. (2012). Signifikansi Pemikiran Homi Bhabha: Sebuah Pengantar Teori Poskolonial. https://ruangberbagiku.wordpress .com/2012/11/22/signifikansipemikiran-homi-bhabha-sebuahpengantar-teori-poskolonial// 